\title{
EVALUATION OF PITUITARY-DEPENDENT HYPERADRENOCORTICISM RESPONSE TO MITOTANE TREATMENT IN DOGS. LENGTH OF INITIAL PHASE OF TREATMENT IN RELATION TO INITIAL VALUE OF URINE CORTISOL/CREATININE RATIO
}

\author{
J. KOLEVSKÁ, M. SVOBODA
}

Small Animal Clinic, Faculty of Veterinary Medicine, University of Veterinary and Pharmaceutical Sciences Brno, Czech Republic

Received February 23, 2001

Accepted August 28, 2001

\section{Abstract}

Kolevská J., M. Svoboda: Evaluation of Pituitary-dependent Hyperadrenocorticism Response to Mitotane Treatment in Dogs. Length of Initial Phase of Treatment in Relation to Initial Value of Urine Cortisol/creatinine Ratio. Acta Vet. Brno 2001, 70: 313-320.

The aim of this work was to evaluate the response of dogs with pituitary-dependent hyperadrenocorticism to treatment with mitotane. The relationship between duration of initial phase of therapy and the initial value of urine cortisol/creatinine ratio (UCCR) was studied. All 14 dogs with pituitary-dependent hyperadrenocorticism were treated. Therapeutic protocol of selective adrenocorticolysis was used. The induction dose of mitotane was $25 \mathrm{mg} / \mathrm{kg}$ daily. The length of initial phase of therapy was determined individually on the basis of cortisol production changes, which were monitored by immunoreactive cortisol in urine (UCCR) every 2-5 days during the initial phase of treatment. High-dose dexamethasone suppression test was used to differentiate between the pituitary-dependent and adrenal-dependent form of the disease, and the UCCR was measured after dexamethasone suppression. The value of the initial UCCR fluctuated between $58-586 \times 10^{-6}$, the median of UCCR was $138 \times 10^{-6}$. Initial phase of therapy lasted 10-64 days. Mean length of initial therapy was 17 days with a median of 14.5 day. The cumulative induction dose of mitotane ranged from 250 to $1600 \mathrm{mg} / \mathrm{kg} \mathrm{b}$.w. No linear dependence between the length of initial phase of therapy and the pre-treatment values of UCCR was found by regression and correlation analysis.

$o, p^{\prime}-D D D$, immunoreactive cortisol in urine, selective adrenocorticolysis, iatrogenic hypoadrenocorticism

There are two forms of spontaneous hyperadrenocorticism, pituitary-dependent and adrenal-dependent. Pituitary-dependent form comprises approximately $85 \%$ of the cases, adrenal-dependent form accounts for $15 \%$ of the cases (Feldman 1996; Rijnberk 1996). There are two possibilities of spontaneous hyperadrenocorticism therapy, surgical or conservative. Choice of the therapeutic approach depends on the location of pathologic process as well as on laboratory and technical equipment available.

Surgical treatment is indicated in cases with diagnosed adrenocortical tumour. The surgical approach (hypophysectomy) can be used in pituitary-dependent hyperadrenocorticism if computed tomography or magnetic resonance imaging are available (Niebauer 1992; Feldman 1996). Since these techniques are still not commonly used in veterinary medicine in this country, we prefer medical treatment to surgical (S voboda et al. 1998). Mitotane in particular is successfully used in dogs, occasionally also ketoconasole or selegilin hydrochloride (Opitz et al. 1983; Peterson 1983; Nichols 1990; Peterson and Kintzer 1994).

Mitotane (o,p'-DDD) is an isomer of the insecticide DDT. Its adrenolytic properties were discovered by Nelson and Woodard in 1949. Mitotane therapy was first used in dogs in 1973

Address for correspondence: MVDr. Jana Kolevská, Ph. D Small Animal Clinic Palackétyo $1-3,61442$ B and Pharmaceutical Sciences Palackého 1-3, 61442 Brno, Czech Republic
Phone:+420 541562814

Mobil: 0602/771 872

E-mail:kolevskaj@email.cz
http://www.vfu.cz/acta-vet/actavet.htm 
(Peterson 1983; Rijnberk et al. 1992). The substance was found to cause adrenal cortex necrosis. Mitotane inhibits intramitochondrial conversion of cholesterol to pregnenolone and 11-deoxycortisol to cortisol. It also interferes with extra-adrenal metabolism of cortisol in that it inhibits the conversion of cortisol into tetrahydrometabolites (Kreeze 1992). Mitotane in small amount causes necrosis of zona fasciculata and zona reticularis, higher and prolonged dosage can impair also zona glomerulosa (Rijnberk and Belshaw 1992). This effect is employed in two basic therapeutic protocols: the method of selective and nonselective adrenocorticolysis.

The aim of this work was to evaluate the reactivity of patients with pituitary-dependent hyperadrenocorticism to mitotane treatment during the initial phase of therapy by using the method of selective adrenocorticolysis. Initial cortisol production and its changes during therapy were monitored by determination of immunoreactive cortisol in urine. Dependence between length of initial treatment and initial value of urine cortisol/creatinine ratio (UCCR) was studied. Other indirect indices of cortisol production (clinical and laboratory signs) are mentioned only before treatment because they were not used for monitoring of changes in cortisol production during therapy.

\section{Materials and Methods}

The studied group consisted of 14 patients, seven females and seven males, with pituitary-dependent hyperadrenocorticism. They exhibited typical clinical and laboratory signs of the disease. The diagnosis and subsequently form of disease were determined on the basis of positive result of the dynamic functional test. No patients with concurrent diabetes mellitus were included.

Full history was taken in each patient with the relevant clinical signs. History questions were especially aimed at water intake and urine excretion, appetite, physical activity of the animal, haircoat changes and their duration, female sexual cycle, libido of males as well as possible changes in the size of testicles. The score system was employed to characterise the clinical signs in greater detail.

Haematological and serum biochemistry tests, urinalysis including urinary sediment, radiography and ultrasound examination were performed. Bacterial culture of urine was carried out only in cases with active urine sediment.

Standard May-Grünwald, Giemsa-Romanovsky staining was used for the differential blood count, the analyser Cobas Mira S was employed for biochemistry testing. Thyroxine was detected by the chemiluminiscence immunoanalysis using the Immulite test system. Mineral levels were determined by spectrophotometer ATOMSPEK (type Hilger 939).

Specific diagnosis was based on the determination of immunoreactive cortisol in urine. Two samples of morning urine taken from each animal were immediately frozen at $-20^{\circ} \mathrm{C}$. The initial urine cortisol/creatinine $(\mathrm{C} / \mathrm{C})$ ratio was measured in each sample. In order to differentiate between the pituitary-dependent and adrenal-dependent form of the disease, high-dose dexamethasone suppression test was performed. The patients were given dexamethasone at a dose of $0.1 \mathrm{mg} / \mathrm{kg} \mathrm{b}$. w. p.o. three times daily $(7,15$, and $23 \mathrm{~h}$ ) from the second day onwards. The last sample of urine was taken in the morning of day 3 to evaluate the suppression rate of $\mathrm{C} / \mathrm{C}$ in relationship to the initial ratio. Immunoreactive cortisol in urine was determined by fluorescence polarisation immunoassay (FPIA) with urine extraction. Dichlormethan was employed for urine extraction. The sets of Abbott Company (for TDx system, No 9116) were used. The lowest detectable amount of cortisol in urine (sensitivity of the used technique) was $17 \mathrm{nmol} / \mathrm{l}$. Cross-reactivity (specificity of the method) with the other endogenous and exogenous corticosteroids was as follows: prednisolone 35\%, 11-deoxycortisol $8.5 \%$, corticosterone $6.3 \%$, 6-methylprednisolone $2.9 \%$, cortisone $2.5 \%$, tetrahydrocortisol $1.4 \%$, 11 deoxycorticosterone $1.1 \%$, prednisone $0.7 \%$, 6-hydroxycortisol $0.7 \%$, dexamethasone $0.4 \%$, 17 hydroxyprogesterone $0.4 \%$. Cross-reactivity with other endogenous and exogenous corticosteroids was lower than $0.1 \%$. The criteria worked out by Rijnberk and Belshaw (1988) were used for evaluation of the dynamic functional tests.

The patients were treated with mitotane. The therapeutic protocol of selective adrenocorticolysis was used. Mitotane was given at $25 \mathrm{mg} / \mathrm{kg}$ b.w. daily during the initial phase of treatment. Length of the initial phase of therapy was determined individually based on monitoring of changes in cortisol production. The changes of cortisol production were quantified by UCCR. This ratio was recorded every 2-5 days of therapy until it dropped to its normal range, i.e. below $10 \times 10^{-6}$. Mitotane was given once per week during the consecutive maintenance phase of therapy. Dosage of mitotane during maintenance phase of treatment was again determined individually on the basis of cortisol production changes (UCCR). During the maintenance phase of therapy the UCCR was monitored every four months.

Regression and correlation analyses were employed to evaluate whether linear dependence exists between the length of the initial phase of therapy and the initial value of the UCCR. 


\section{Results}

The age of examined patients ranged from 5 to 12 years (average $9.21 \pm 2.00$ ). Mean weight of the patients was $12.6 \pm 2.4 \mathrm{~kg}$. Breeds were represented as follows: 4 dachshunds, 3 poodles, 2 schnauzers, 1 springer spaniel, spitz, Shetland sheepdog, German pinscher, and boxer. The occurrence and intensity of individual clinical symptoms are shown in Table 1. The haematological profile demonstrated leukocytosis in four patients $(28.5 \%)$, neutrophilia in 12 patients $(85.7 \%)$, eosinopenia in 13 patients $(92.8 \%)$ significant lymphopenia in 8 dogs $(57.0 \%)$, monocytosis in one case $(7.1 \%)$. Changes in biochemical profile are shown in Table 2. The results of urinalysis revealed isosthenuria in six patients $(42.8 \%)$, hyposthenuria in four patients $(28.5 \%)$, and in three cases $(21.4 \%)$ the specific gravity of the urine ranged from 1,012 to 1,020 , and one $\operatorname{dog}(7.1 \%)$ had hypersthenuria. Proteinuria was found in eight dogs $(57.1 \%)$; no glycosuria was recorded. Active urine sediment was found in three cases $(21.4 \%)$. Subsequent bacterial culture of the urine was negative in one case and positive for Escherichia coli in two cases. Radiographs confirmed hepatomegaly in 13 dogs $(92.8 \%)$, uroliths in 3 cases $(21.4 \%)$, and bronchial calcification in 1 case $(7.1 \%)$. Ultrasonography revealed bilaterally enlarged adrenal glands (from 1.5 to $3 \mathrm{~cm}$ ) in 9 patients $(64.2 \%)$, in 3 cases $(21.4 \%)$ only enlarged left adrenal gland was visualised, and in one case $(7.1 \%)$ we were not able to find the adrenal glands. In order to confirm diagnosis, the initial UCCR was measured in two morning samples. The mean value of UCCR fluctuated between $58-586 \times 10^{-6}$ (Table 3 ). The mean value of UCCR was $199.2 \pm 176.7 \times 10^{-6}$, the median of UCCR was $138.2 \times 10^{-6}$. In order to differentiate between the pituitary-dependent and adrenal-dependent form of the disease, the UCCR was recorded after the administration of high dose of dexamethasone; in all cases the UCCR was suppressed by more than $50 \%$ in comparison with the initial values.

The therapeutic protocol of selective adrenocorticolysis was employed in all patients. The patients were monitored every 2-5 days during the initial phase of therapy till the UCCR declined below the limit of reference range. The results obtained during the initial phase of therapy are shown in Table 3, 4, 5 and Fig. 1 and 2. Three patients (21.4\%) suffered from anorexia and mild weakness during mitotane treatment but recovered after withdrawal of the drug for several days, and therapy could continue. The substitution therapy with glucocorticoids and mineralocorticoids was never necessary. The median of length of the initial therapy was 14.5 day. The mean length of the initial therapy was $17 \pm 13$ days. The cumulative induction dose of mitotane ranged from 250 to $1600 \mathrm{mg} / \mathrm{kg} \mathrm{b.w}$. The regression and correlation analyses were used to determine linear dependence between the length of the initial phase of therapy and the level of the initial UCCR. The correlation coefficient 0.54 was not statistically significant. The coefficient of determination was 0.08 , the test criterion F (1.06) was compared with the quantiles of Snedecor's distribution. We found that the regression function was not significant. There was no linear dependence between both studied parameters.

Weekly dosage of mitotane ranged from 25 to $100 \mathrm{mg} / \mathrm{kg} \mathrm{b}$. w. during the maintenance phase of therapy and was individually determined in each patient by means of the UCCR monitoring. The patients were and still are being monitored during the maintenance phase of therapy every four months.

Relapses were recorded in three cases $(21.4 \%)$ (up to one year from the onset of therapy). Neither clinical signs nor laboratory symptoms indicated deficit of glucocorticoids and mineralocorticoids in any patient during the maintenance phase of treatment. No symptoms of intolerance to mitotane therapy were ascertained. The aim of the present work was not to evaluate the outcome of the maintenance phase of treatment, and therefore the results are not summarised in detail. Some patients cannot be evaluated because only a short time interval has elapsed from the onset of therapy. 
Table 1

Clinical signs of patients with pituitary-dependent hyperadrenocorticism

\begin{tabular}{|c|c|c|c|c|c|c|c|}
\hline $\begin{array}{c}\text { Patient } \\
\text { number }\end{array}$ & $\begin{array}{c}\text { Polyuria } \\
\text { and polydipsia }\end{array}$ & Polyphagia & Apathy & $\begin{array}{c}\text { Skin } \\
\text { problems }\end{array}$ & $\begin{array}{c}\text { Muscle } \\
\text { weakness }\end{array}$ & $\begin{array}{c}\text { Sexual } \\
\text { function disorders }\end{array}$ & $\begin{array}{c}\text { Pendulous } \\
\text { abdomen }\end{array}$ \\
\hline 1 & ++ & +++ & ++ & +++ & ++ & ++ & + \\
\hline 2 & ++ & +++ & ++ & ++++ & ++ & ++ & + \\
\hline 3 & ++ & ++ & 0 & ++ & + & 0 & + \\
\hline 4 & +++ & ++ & + & +++ & ++ & + & 0 \\
\hline 5 & + & 0 & + & + & 0 & + & + \\
\hline 6 & +++ & ++ & + & + & + & + & + \\
\hline 7 & +++ & ++ & + & +++ & 0 & 0 & + \\
\hline 8 & +++ & + & ++ & +++ & ++ & ++ & + \\
\hline 9 & +++ & +++ & ++ & ++ & ++ & + & + \\
\hline 10 & +++ & ++ & ++ & +++ & ++ & 0 & + \\
\hline 11 & +++ & +++ & ++ & + & ++ & + & 0 \\
\hline 12 & +++ & ++ & + & +++ & ++ & ++ & + \\
\hline 13 & +++ & +++ & ++ & + & ++ & ++ & + \\
\hline 14 & +++ & + & + & 0 & 0 & 0 & 0 \\
\hline
\end{tabular}

PU/PD

$\begin{array}{ll}0 & \text { fluid intake in physiologic range } \\ + & 100-150 \mathrm{ml} / \mathrm{kg} \mathrm{b} . w . / \mathrm{d} \\ ++ & 151-200 \mathrm{ml} / \mathrm{kg} \mathrm{b} . \mathrm{w} . / \mathrm{d} \\ +++ & 201-300 \mathrm{ml} / \mathrm{kg} \mathrm{b.w./d} \\ ++++ & 301 \mathrm{ml} / \mathrm{kg} \mathrm{b.w./d} \mathrm{and} \mathrm{more}\end{array}$

Polyphagia

$0 \quad$ not present

$+\quad$ food intake two times more in comparison with normal

$+\quad$ enhanced food intake approximately two times in comparison with normal

$++\quad$ enhanced food intake more than two times in comparison with normal

\section{Skin symptoms of disease}

$0 \quad$ not present

$+\quad$ symmetric focal hypotrichosis

$++\quad$ symmetric focal hairlessness

$++\quad$ symmetric hypotrichosis of the whole body

$++++\quad$ symmetric hairlessneess of the whole body

\section{Sexual function disorders}

$\begin{array}{ll}\text { in female } & \text { oestrus disorders } \\ 0 & \text { not present } \\ + & \text { oestrus cycle irregularity } \\ ++ & \text { oestrus cycle skipping }\end{array}$

\section{Apathy \\ 0 not present \\ + mild apathy \\ ++ marked apathy}

\section{Pendulous abdomen}

0 no

+ yes

Muscle weakness

0 not present

+ mild muscle weakness

++ marked muscle weakness

$$
\begin{array}{ccl}
\text { in male } & \multicolumn{3}{c}{\text { testicular atrophy }} \\
& 0 & \text { not present } \\
& + & \text { mild atrophy } \\
& ++ & \text { marked atrophy }
\end{array}
$$

\section{Discussion}

There are two therapeutic protocols of conservative mitotane therapy: method of nonselective and method of selective adrenocorticolysis. The second method has two phases: initial and maintenance. The aim of initial phase is to decrease cortisol production into reference range, the aim of maintenance phase is to keep it within reference range. The initial daily induction dose of mitotane $25-50 \mathrm{mg} / \mathrm{kg}$ causes destruction of zona fasciculata and zona reticularis while zona glomerulosa usually remains unaffected. However, in some patients the 
Table 2.

Biochemical indices in patients with pituitary-dependent hyperadrenocorticism

\begin{tabular}{|l|c|c|c|c|}
\hline \multicolumn{1}{|c|}{$\begin{array}{c}\text { Biochemical indices (unit) } \\
\text { (serum) }\end{array}$} & Median & $\begin{array}{c}\text { Arithmetical } \\
\text { mean }\end{array}$ & S.E.M. & $\begin{array}{c}\text { Variation } \\
\text { range }\end{array}$ \\
\hline ALP $(\mu \mathrm{kat} / \mathrm{l})$ & 14.28 & 17.52 & 17.07 & 64.8 \\
\hline ALT $(\mu \mathrm{kat} / \mathrm{l})$ & 1.54 & 2.86 & 2.89 & 10.0 \\
\hline Glucose $(\mathrm{mmol} / \mathrm{l})$ & 5.98 & 5.96 & 0.87 & 2.9 \\
\hline Cholesterol $(\mathrm{mmol} / \mathrm{l})$ & 9.73 & 9.20 & 1.71 & 5.88 \\
\hline Sodium $(\mathrm{mmol} / \mathrm{l})$ & 145.0 & 145.20 & 2.60 & 10.0 \\
\hline Potassium $(\mathrm{mmol} / \mathrm{l})$ & 4.39 & 4.28 & 0.47 & 1.7 \\
\hline Phosphorus $(\mathrm{mmol} / \mathrm{l})$ & 1.59 & 1.45 & 0.34 & 0.9 \\
\hline $\mathrm{T}_{4}(\mathrm{nmol} / \mathrm{l})$ & 12.39 & 13.34 & 5.02 & 14.3 \\
\hline
\end{tabular}

Table 3

Length of the initial therapy in individual patients, UCCR before and after treatment

\begin{tabular}{|c|c|c|c|}
\hline \multirow{2}{*}{ Patient number } & \multicolumn{2}{|c|}{ UCCR $\left(\times 10^{-6}\right)$} & $\begin{array}{c}\text { Length of the initial } \\
\text { therapy } \\
\text { (days) }\end{array}$ \\
\cline { 2 - 4 } & Initial & $\begin{array}{c}\text { After the initial } \\
\text { therapy }\end{array}$ & 16 \\
\hline 1 & 163.1 & 5.6 & 20 \\
\hline 2 & 204.8 & 4.8 & 12 \\
\hline 3 & 62.2 & 6.8 & 12 \\
\hline 4 & 64.7 & 4.8 & 10 \\
\hline 5 & 59.9 & 6.0 & 12 \\
\hline 6 & 76.6 & 3.8 & 14 \\
\hline 7 & 94.8 & 7.5 & 15 \\
\hline 8 & 58.4 & 6.1 & 64 \\
\hline 9 & 528.3 & 8.3 & 18 \\
\hline 10 & 130.1 & 5.4 & 12 \\
\hline 11 & 224.0 & 5.5 & 18 \\
\hline 12 & 146.2 & 6.8 & 16 \\
\hline 13 & 586.6 & 4.6 & 10 \\
\hline 14 & 389.3 & 7.5 & \\
\hline
\end{tabular}

Table 4

UCCR during the initial therapy

\begin{tabular}{|c|c|c|c|c|c|c|c|c|c|c|}
\hline \multirow{2}{*}{$\begin{array}{c}\text { Patient } \\
\text { number }\end{array}$} & \multicolumn{10}{|c|}{ UCCR $\left(\times 10^{-6}\right)$} \\
\hline & Initial & Day 9 & Day 10 & Day 12 & Day 13 & Day 14 & Day 15 & Day 16 & Day 18 & Day 20 \\
\hline 1 & 163.1 & $\mathrm{x}$ & 120.6 & $\mathrm{x}$ & 28.6 & $\mathrm{x}$ & $\mathrm{x}$ & 5.6 & $\mathrm{x}$ & $\mathrm{x}$ \\
\hline 2 & 204.8 & $\mathrm{x}$ & 168.4 & $\mathrm{x}$ & $\mathrm{x}$ & $\mathrm{x}$ & 118.2 & $\mathrm{x}$ & $\mathrm{x}$ & 4.8 \\
\hline 3 & 62.2 & $\mathrm{x}$ & 28.8 & 6.8 & $\mathrm{x}$ & $\mathrm{x}$ & $\mathrm{x}$ & $\mathrm{x}$ & $\mathrm{x}$ & $\mathrm{x}$ \\
\hline 4 & 64.7 & $\mathrm{x}$ & 54.2 & 4.8 & $\mathrm{x}$ & $\mathrm{x}$ & $\mathrm{x}$ & $\mathrm{x}$ & $\mathrm{x}$ & $\mathrm{x}$ \\
\hline 5 & 59.9 & $\mathrm{x}$ & 6.0 & $\mathrm{x}$ & $\mathrm{x}$ & $\mathrm{x}$ & $\mathrm{x}$ & $\mathrm{x}$ & $\mathrm{x}$ & $\mathrm{x}$ \\
\hline 6 & 76.6 & $\mathrm{x}$ & 48.0 & 3.8 & $\mathrm{x}$ & $\mathrm{x}$ & $\mathrm{x}$ & $\mathrm{x}$ & $\mathrm{x}$ & $\mathrm{x}$ \\
\hline 7 & 94.8 & $\mathrm{x}$ & 74.2 & $\mathrm{x}$ & $\mathrm{x}$ & 7.5 & $\mathrm{x}$ & $\mathrm{x}$ & $\mathrm{x}$ & $\mathrm{x}$ \\
\hline 8 & 58.4 & $\mathrm{x}$ & 22.0 & $\mathrm{x}$ & $\mathrm{x}$ & $\mathrm{x}$ & 6.1 & $\mathrm{x}$ & $\mathrm{x}$ & $\mathrm{x}$ \\
\hline 10 & 130.1 & $\mathrm{x}$ & 98.4 & $\mathrm{x}$ & $\mathrm{x}$ & $\mathrm{x}$ & 34.0 & $\mathrm{x}$ & 5.4 & $\mathrm{x}$ \\
\hline 11 & 224.0 & 18.7 & $\mathrm{x}$ & 5.5 & $\mathrm{x}$ & $\mathrm{x}$ & $\mathrm{x}$ & $\mathrm{x}$ & $\mathrm{x}$ & $\mathrm{x}$ \\
\hline 12 & 146.2 & $\mathrm{x}$ & 126.3 & $\mathrm{x}$ & $\mathrm{x}$ & $\mathrm{x}$ & 12.8 & $\mathrm{x}$ & 6.8 & $\mathrm{x}$ \\
\hline 13 & 586.7 & $\mathrm{x}$ & 108.0 & $\mathrm{x}$ & 86.0 & $\mathrm{x}$ & $\mathrm{x}$ & 4.6 & $\mathrm{x}$ & $\mathrm{x}$ \\
\hline 14 & 389.3 & $\mathrm{x}$ & 7.5 & $\mathrm{x}$ & $\mathrm{x}$ & $\mathrm{x}$ & $\mathrm{x}$ & $\mathrm{x}$ & $\mathrm{x}$ & $\mathrm{x}$ \\
\hline
\end{tabular}

$\mathrm{x}$ - not measured 
Table 5

UCCR during the initial therapy in patient No 9

\begin{tabular}{|c|c|}
\hline Day of therapy & UCCR $\left(\times 10^{-6}\right)$ \\
\hline 1 & 528.3 \\
\hline 10 & 543.2 \\
\hline 15 & 513.4 \\
\hline 20 & 1100.0 \\
\hline 25 & 558.6 \\
\hline 30 & 406.0 \\
\hline 35 & 772.5 \\
\hline 40 & 377.9 \\
\hline 45 & 312.6 \\
\hline 50 & 170.1 \\
\hline 60 & 12.2 \\
\hline 64 & 8.3 \\
\hline
\end{tabular}

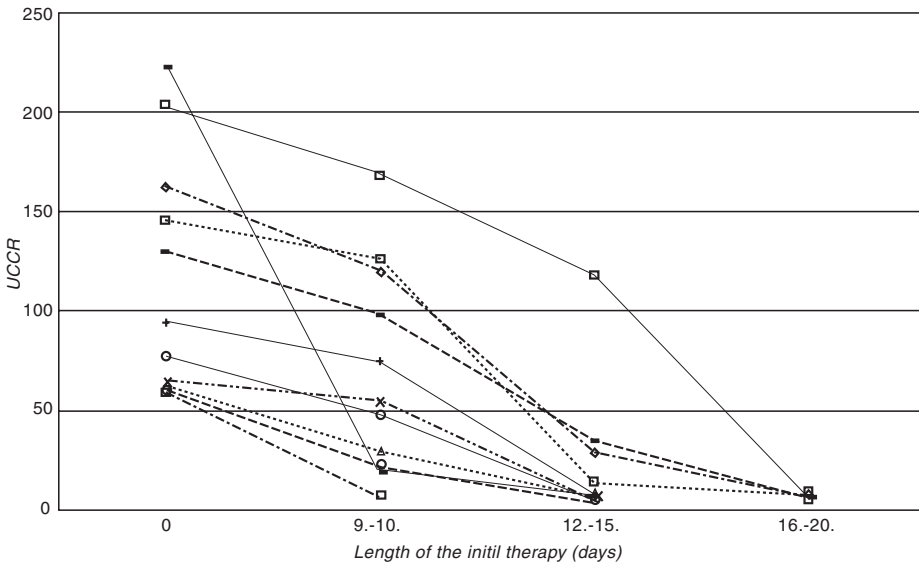

-- Patient 1 $\rightarrow$ - Patient 2

-........ Patient 3

-**.* Patient 4

- Patient 6

- Patient 7

$-0-$ Patient 8
-- - Patient 10
$-0-$ Pat

- Patient 11

-...-... Patient 12

Fig. 1: Course of the initial therapy

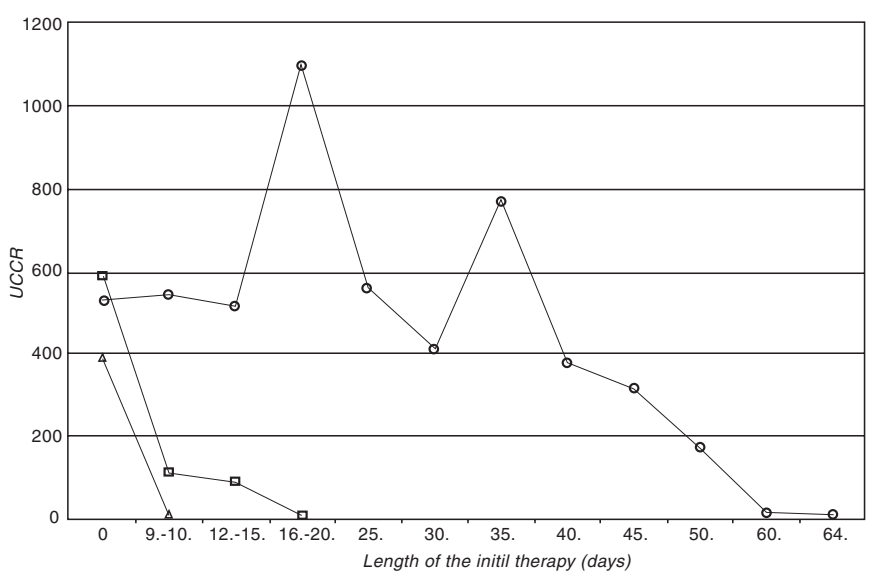

Fig. 2: Course of the initial therapy 
destruction of zona glomerulosa can occur at this dosage as well as the iatrogenic Addison's disease can be triggered (Schechter et al. 1973; Feldman et al. 1992). The patient is monitored by ACTH stimulation test or UCCR during therapy in order to prevent the unexpected induction of hypoadrenocorticism (Feldman 1996; Rijnberk 1996). The other treatment protocol is the method of non-selective adrenocorticolysis to initiate Addison's disease. This treatment protocol was worked out by Rijnberk and Belshaw (1988). Mitotane is continued at a maintenance dose of $50-75 \mathrm{mg} / \mathrm{kg} \mathrm{b}$. w. daily (in toy breeds up to $100 \mathrm{mg} / \mathrm{kg}$ b.w. daily) for 25 consecutive days. Since the objective of this protocol is to induce hypoadrenocorticism, the patient is given glucocorticoids and mineralocorticoids from the third day of therapy. The substitution therapy is life-long; its interruption can cause exitus. Monitoring of this treatment protocol is less laborious than during the selective adrenocorticolysis. The UCCR is measured only before the onset of therapy and one month after cessation of treatment. Continuous monitoring in stabilised patient is recommended in both treatment protocols every four months of therapy. Rijnberk and Belshaw (1992) reported up to $33 \%$ recurrence rate within one year when using the method of non-selective adrenocorticolysis mentioned above, ACTH stimulation test or UCCR can be used for evaluation of changes in cortisol production during mitotane therapy. Other indirect indices of cortisol production (rate of PU/PD, polyphagia, evaluation of changes in haematological and biochemical profile) are inaccurate and therefore associated with high risk when establishing the length of initial phase of therapy (Feldman 1996). Only pre-treatment clinical and laboratory signs are therefore mentioned in the present work. The immunoreactive cortisol measurement in urine was used as well as UCCR for direct quantification of changes in cortisol production during therapy. Therapy with mitotane can be summarised as follows: The duration of the initial therapy ranged from 10 to 64 days. The mean length of initial therapy (dose of mitotane $25 \mathrm{mg} / \mathrm{kg} \mathrm{b.w.)} \mathrm{was} 17 \pm 13$ days, the median of the length of initial phase of therapy was 14.5 day. By Kintzer and Peters on (1991) the mean length of initial therapy during mitotane treatment at a dosage of $50 \mathrm{mg} / \mathrm{kg} \mathrm{b}$. w. daily was nine days, with the possible fluctuation from 5 to 60 days. Fergus on et al. (1992) reported the mean length of initial therapy during the same dosage of mitotane 14 days with the possible fluctuation from 2 to 35 days. The cumulative induction dose of mitotane ranged between 250 and $1600 \mathrm{mg} / \mathrm{kg} \mathrm{b}$. w. Kintzer and Peters on (1994) reported the mean induction dose of mitotane in patients with the pituitary-dependent hyperadrenocorticism $400-500 \mathrm{mg} / \mathrm{kg} \mathrm{b}$. w., while in patients with adrenocortical tumour the induction dosages are approximately ten times higher.

Further goal of this work was to find if linear dependence exists between the length of initial therapy and the level of the initial UCCR. We have found no linear dependence between both parameters. The obtained results documented the strongly individual reaction of patients during mitotane therapy which is to a great extent unpredictable. There is a need of an individual approach in each patient, because there is no generally applicable scheme of the length of initial therapy that could be employed on the basis of the knowledge of initial cortisol production. Using the selective adrenocorticolysis, frequent and expensive monitoring is necessary for the desired effect of therapy as well as for reduction of the risk of iatrogenic hypoadrenocorticism.

\section{Hodnocení odpovídavosti psů s centrálním hyperadrenokorticizmem na léčbu mitotanem, sledování úvodní fáze terapie ve vztahu k iniciální hodnotě poměru kortizol/kreatinin v moči}

Hlavním cílem práce bylo hodnocení odpovídavosti psů s centrálním hyperadrenokorticizmem na léčbu mitotanem. Byl sledován vztah mezi délkou úvodní fáze terapie a hodnotou iniciálního poměru kortizol/kreatinin $(\mathrm{C} / \mathrm{C}) \mathrm{v}$ moči. $\mathrm{K}$ léčbě bylo přistoupeno celkem u 14 psů s centrálním hyperadrenokorticizmem. Byl zvolen terapeutický protokol 
parciální destrukce kůry nadledvin. Mitotan byl v průběhu úvodní fáze léčby podáván v dávce $25 \mathrm{mg} / \mathrm{kg}$ ž.hm./d. Délka iniciální fáze terapie byla určována u každého pacienta individuálně a to na základě změn $\mathrm{v}$ produkci kortizolu, které byly monitorovány stanovováním imunoreaktivního kortizolu v moči (poměru $\mathrm{C} / \mathrm{C}$ ) každých 2 - 5 dní úvodní fáze léčby. $\mathrm{K}$ rozlišení centrální a periferní formy onemocnění byl užit supresní test s vysokou dávkou dexametazonu, byl stanovován poměr $\mathrm{C} / \mathrm{C}$ po supresi dexametazonem. Výše iniciálního poměru $\mathrm{C} / \mathrm{C}$ se v souboru pacientů pohybovala v rozmezí $58-586 \times 10^{-6}$, medián poměru byl $138 \times 10^{-6}$. Celková délka úvodní fáze léčby se pohybovala v rozmezí 10 - 64 dní. Průměrná délka iniciální terapie byla 17 dní, medián byl 14,5 dne. Celková indukční dávka mitotanu byla v rozmezí 250 - $1600 \mathrm{mg} / \mathrm{kg}$ ž.hm. S využitím regresní a korelační analýzy bylo sledováno, zda existuje lineární závislost mezi délkou iniciální fáze terapie a hodnotou poměru $\mathrm{C} / \mathrm{C}$ před zahájením léčby. Bylo zjištěno, že oba uvedené parametry na sobě nejsou lineárně závislé.

\section{Acknowledgements}

This work was supported by grant of the Ministry of Education, Youth and Sports of the Czech Republic No 161700002.

\section{References}

FELDMAN, E. C. 1996: Hyperadrenocorticism. In: Canine and feline endocrinology and reproduction (E. C. Feldman, R. W. Nelson, eds.) W. B. Saunders Comp., Philadelphia, pp. 187-261

FELDMAN, E. C., NELSON, R. W., FELDMAN, M. S., FARVER, T. B. 1992: Comparison of mitotane treatment for adrenal tumor versus pituitary-dependent hyperadrenocorticism in dogs. J. Am. Vet. Med. Assoc. 200: 1642-1646

FERGUSON, D., HOENIG, M., CORNELIUS, M. 1992: Hyperadrenocorticism. In: Small animal medical therapeutics. (M. D. Lorenz, L. J. Cornelius, D. C. Ferguson, eds.) Lippincott Comp., Philadelphia, pp. 104-117

KINTZER, P. P., PETERSON, M. E. 1991: Mitotane (o,p'-DDD) treatment of 200 dogs with pituitary-dependent hyperadrenocorticism. J. Vet. Int. Med. 5: 18-27

KINTZER, P. P., PETERSON, M. E. 1994: Mitotane (o,p'-DDD) treatment of dogs with cortisol-secreting adrenocortical neoplasia: 32 cases $(1980$ - 1992). J. Am. Vet. Med. Assoc. 205: 54-61

KREEZE, A. 1992: Cushingov syndróm. Martin, Osveta, 226 p.

NICHOLS, R. 1990: Problems associated with the medical therapy of canine hyperadrenocorticism. Probl. Vet. Med. 2: $551-556$

NIEBAUER, G. W. 1992: Hypophysectomy. In: Textbook of small animal surgery, (D. H. Slatter, ed.) $2^{\text {nd }}$ edition, Philadelphia, W. B. Saunders Comp., pp. 1496-1510

OPITZ, M., LETTOW, E., LOPPNOW, H., GREVEL, V. 1983: Experiences with Lysodren treatment of Cushing's syndrome in dogs. Tierarztl. Prax. 11: 507-520

PETERSON, M. E. 1983: o,p'-DDD (mitotane) treatment of canine pituitary-dependent hyperadrenocorticism. J. Am. Vet. Med. Assoc. 182: 527-528

PETERSON, M. E., KINTZER, P. P. 1994: Medical treatment of pituitary-dependent hyperadrenocorticism in dogs. Semin. Vet. Med. Surg. Small Anim. 9: 127-131

RIJNBERK, A. 1996: Adrenals. In: Clinical endocrinology of dogs and cats. (A. Rijnberk, ed.) Kluwer Academic Publishers, Dordrecht, pp. 61-93

RIJNBERK, A., BELSHAW, B. E. 1988: An alternative protocol for the medical management of canine pituitarydependent hyperadrenocorticism. Vet. Rec. 122: 486-488

RIJNBERK, A., BELSHAW, B. E. 1992: O,p'-DDD treatment of canine hyperadrenocorticism: an alternative protocol. In: Current veterinary therapy XI. (R. W. Kirk, Bonagura, J. D., eds.) Philadelphia, W. B. Saunders Comp., pp. 345-349

RIJNBERK, A., WESS, A., MOL, J. A. 1988: Assessment of two tests for the diagnosis of canine hyperadrenocorticism. Vet. Rec. 122: 178-180

SCHECHTER, R. D., STANBENFELDT, G. H., GRIBBLE, D. H. 1973: Treatment of Cushingęs syndrome in dogs with an adrenocorticolytic agent (o,p'-DDD). J. Am. Vet. Med. Assoc. 162: 629-639

SVOBODA, M., DOUBEK, J., KOLEVSKÁ, J., ČADA, F. 1998: Hyperadrenokorticizmus. In: Endokrinologie psa a kočky. (M. Svoboda, J. Doubek, eds.) CAVLMZ Brno, pp. 112-130. 